\title{
Profesní činnosti učitelek mateřských škol ve světle současných českých výzkumů
}

\author{
Radmila Burkovičováa, Jana Kropáčkováb \\ ${ }^{a}$ Ostravská univerzita v Ostravě, Pedagogická fakulta, \\ Katedra preprimární a primární pedagogiky

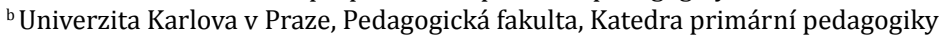 \\ Redakci zasláno 13. 5. 2014 / upravená verze obdržena 22. 9. 2014 / \\ k uveřejnění přijato 26. 9. 2014
}

\begin{abstract}
Abstrakt: Cílem empirické studie je prezentovat výsledky výzkumů profesních činností učitelek mateřských škol a vymezit charakteristické znaky profese učitelky mateřské školy v českém prostředí. V první části autorky dokládají zvyšující se odborný zájem o profesi učitelství v České republice, sumarizují poznatky dostupných výzkumů profesních činností učitelů a ve druhé části charakterizují kategorii učitelek mateřských škol, která představuje významnou skupinu v českém regionálním školství. Ve stěžejní třetí části je prezentováno výzkumné šetření, jehož hlavním cílem bylo identifikovat, pojmenovat a zaznamenat učitelkou české mateřské školy běžného typu profesní činnosti jí reálně vykonávané, ověřit jejich existenci a zjistit ve třech obdobích školního roku podíl časového vytížení učitelky realizací vybraného druhu činnosti v rámci určené týdenní přímé práce s dětmi. Závěrečná část studie naznačuje několik cest, jak by bylo možné s výsledky výzkumů dále pracovat.
\end{abstract}

Klíčová slova: učitelka mateřské školy, profesní činnosti, učitelská profese, preprimární vzdělávání

Učitelské profesi se v posledních letech věnuje zvýšená pozornost, avšak většina výzkumů je zaměřena na kategorii učitelů základních či středních škol. Předložená studie nabízí pohled na profesi učitelek mateřských škol. Profese učitele/učitelky mateřské školy ${ }^{1} \mathrm{v}$ České republice má dlouholetou tradici a do jisté míry je odrazem postavení a významu předškolní výchovy nejen ve školském systému, ale i v celé společnosti (Opravilová, 1988, 2007; Uhlírová, 2007).

1 Autorky budou $\mathrm{v}$ textu používat termín učitelka mateřské školy, přestože $\mathrm{v}$ Zákonu č. 563/2004 Sb., o pedagogických pracovnících se uvádí učitel mateřské školy a to s ohledem ke skutečné genderové struktuře této profese v ČR, kde je minimální zastoupení mužů. 
V souvislosti s rozšířením pregraduální př́ípravy učitelů preprimárního vzdělávání formou bakalářského studia Učitelství pro mateřské školy na všech 9 pedagogických fakultách v ČR a Fakultu humanitních studií UTB ve Zlíně se profese učitelky mateřské školy dostává do centra odborné i výzkumné pozornosti (Syslová \& Najvarová, 2012).

V posledních letech je považováno za důležité, aby se na tvorbě nových poznatků podíleli i sami učitelé, a aby byla součástí tvorby i jejich teoretická reflexe praktických zkušeností. Zřetelně je artikulován požadavek podporovat spolupráci učitelů v rozvoji profesního poznání a ve vytváření poznatkové báze učitelství (Janík, 2005; Shulman, 1987; Starý et al., 2012). Prostřednictvím výzkumného šetření prezentovaného ve třetí kapitole, do něhož se zapojily některé učitelky mateřských škol, jsme tak vzájemně spolupracovali při budování poznatkové základny v oblasti profesních činností. Po kategorizaci profesních činností učitelek mateřských škol jsme analyzovali a porovnali časovou vytíženost učitelky identifikovanými činnostmi ve třech obdobích školního roku.

Autorky této studie vymezují dva cíle. Prvním cílem je analyzovat výsledky rozsáhlého českého výzkumu (Burkovičová, 2012) zaměřujícího se na kategorizaci konkrétních profesních činností učitelky české mateřské školy a porovnat časovou vytíženost jedné vybrané činnosti v průběhu školního roku. Druhým cílem je poukázat na specifika profese učitelky mateřských škol v historické perspektivě a ve světle výzkumů věnujících se profesi učitelství v České republice.

\section{Teoretická východiska}

\subsection{Současné poznatky o profesi učitelstvív České republice}

Profesi učitelství je v České republice od 90. let minulého století věnován zvýšený odborný zájem, což dokladují vydané samostatné monografie (Dytrtová \& Kruhutová, 2009; Kurelová, 1998, 2008; Lazarová, 2001; Lukášová, 2003; Průcha, 2002; Spilková \& Hejlová, 2010; Spilková \& Tomková, 2010; Šimoník, 1994; Švec, 1999; Švec, 2000; Švec, 2005; Starý et al., 2012; Vašutová, 2004 atd.), sborníky z konferencí ČPdS a ČAPV (Franiok \& Knotová, 2008; Mareš, 1993; Rybičková \& Hladík, 2009; Škoda \& Doulík, 2004; Švec, 2001; Urbánek, 2001; Urbánek, 2011; Walterová, 2001 atd.) a taktéž stati v odborných časopisech Pedagogika, Pedagogická orientace, Orbis scholae, aj. 
Profese učitelství má svá specifika a v posledních letech se velmi proměnila (Kotaa, 2008; Průcha, 2009; Spilková \& Tomková, 2010; Urbánek, 2005; Vašutová, 2004 atd.). Současný učitel je vystaven nárokům dnešní konzumní společnosti a čelí tak řadě nových problémů (Helus, 2011). Otázkou zůstává, co je pro úspěšné vykonávání učitelské profese nutné a jaké činnosti musí učitel vykonávat. Vašutová (2004) prezentuje obvyklé typologie znalostí učitele a zároveň zdůrazňuje, že v českých zemích se více operovalo s termínem „dovednostní model učitelovy profese," jehož propagátorem byla např. Vyskočilová (2000, s. 25). Dovednost popsala jako integraci senzomotorické činnosti s činností intelektuální, a vysvětlovala, že učitel potřebuje být v kondici, nebot' neustále vstupuje do rizikových situací a vede vlastní dialog o možných variantách řešení.

\subsection{Profesní činnosti ve výzkumech v českém prostředí}

Pro ukotvení výzkumného šetření prezentovaného ve třetí kapitole jsme vyšli z poznatků o dostupných současných výzkumech v českém prostředí. Tyto výzkumy se zaměřují na učitele základních a středních škol, u nichž je struktura profesních činností sice odlišná než u učitelek mateřských škol, přesto však mohou posloužit jako inspirace. Celkově lze konstatovat, že o svou činnost se v minulosti sami pedagogové zajímali. V odborných článcích a monografiích lze dohledat, jak jednotliví autoři prezentují a analyzují profesní činnosti učitele, především se jedná o jejich identifikaci, kategorizaci a proporcionalitu. $\mathrm{V}$ českém prostředí byly výzkumně sumarizovány relativně bohaté poznatky především o konkrétních profesních aktivitách učitelů základních a středních škol (Blížkovský, Kučerová, \& Kurelová, 2000).

Detailní analýze učitelské profese se věnoval Pařízek (1988), který zdůraznil společenské požadavky na učitele $\mathrm{v}$ jejich vztahu k reálnému průběhu jeho činnosti. Na základě výzkumného šetření specifikoval činnosti učitele, které označil jako pracovní: vyučování ve tř̌́dě; organizační a administrativní práce; mimotřídní a mimoškolní činnost žáků; kontakt s rodiči; veřejná činnost; akce školské správy; příprava na vyučování a studium; materiálně technické práce (Pařízek, 1988, s. 64). Za základní činnost učitele uvedl vyučování, v jehož rámci učitel realizuje činnost plánování, uskutečňování a hodnocení (Pařízek, 1988, s. 96). Další dílčí činnosti vymezuje v rámci jednotlivých etap činností, které označuje jako běžné činnosti učitele. Jako hlavní činnosti učitele při vyučování uvedl: motivaci žáků k učení; konkretizaci cílů a obsahu vyučovací jednotky; užití prostředků vyučování včetně metod kontroly vý- 
sledků učení; výchovné působení učitele při vyučování, přičemž rozhodující činností je u učitele formulace cílů (Pařízek, 1988, s. 113).

Zajímavý př́stup ke klasifikaci odborných činností učitele prezentoval Blížkovský (1997), který vycházel z tzv. otevřeného modelu pedagogického procesu a rozlišil čtyři základní druhy pedagogických činností učitelů a vychovatelů, které označil jako profesionální činnosti. V tomto základním rozdělení se shoduje s Kurelovou (1998), která se taktéž věnovala kategorizaci profesních činností učitelů (blíže viz tabulka 1).

Tabulka 1

Základní kategorizace profesních činností učitele

\begin{tabular}{|c|c|}
\hline Blížkovský (1997, s. 94): & Kurelová (1998, s. 16): \\
\hline $\begin{array}{l}\text { pedagogické činnosti komunikativní, které } \\
\text { odpovídají dialektickým vztahům subjektů } \\
\text { a objektů výchovy; }\end{array}$ & $\begin{array}{l}\text { orientační, komunikativní a kultivační } \\
\text { činnosti, odvozené od subjektově- } \\
\text { objektových vztahů výchovy; }\end{array}$ \\
\hline $\begin{array}{l}\text { pedagogické činnosti diagnostické, jež jsou } \\
\text { zaměřeny na analýzu výchovně vzdělávacích } \\
\text { výsledků a podmínek; }\end{array}$ & $\begin{array}{l}\text { diagnostické a evaluační činnosti, jež jsou } \\
\text { odvozené od podmínek výchovy a výchovně- } \\
\text { vzdělávacích výsledků; }\end{array}$ \\
\hline $\begin{array}{l}\text { pedagogické činnosti projektivní, které jsou } \\
\text { orientovány k budoucí dimenzi výchovy, } \\
\text { především k jejich cílům; }\end{array}$ & $\begin{array}{l}\text { projektivní činnosti, které odpovídají } \\
\text { projektování výchovy a vzdělávaní } \\
\text { na různých úrovních fungování školy; }\end{array}$ \\
\hline $\begin{array}{l}\text { pedagogické činnosti realizační představující } \\
\text { tvorbu a optimalizaci pedagogického procesu, } \\
\text { tvưrčí dialektickou integraci a syntézu } \\
\text { všech jeho systémotvorných prvků, vztahů } \\
\text { i vývojových sil. }\end{array}$ & $\begin{array}{l}\text { realizační činnosti odvozené od tvorby } \\
\text { a optimalizace pedagogického procesu. }\end{array}$ \\
\hline
\end{tabular}

Prezentované taxonomie profesních činností se vztahují na učitele základních a středních škol, v českém prostředí, z čehož vychází Průcha (2002, s. 40), který na základě analýzy dostupných výzkumů uvádí 3 kategorie činností učitele: vyučování, činnosti související s vyučováním a jiné činnosti. Podobně i Vašutová (2004) rozlišuje v učitelské profesi činnosti hlavní a další činnosti. Hlavní činností je vyučování ve školní třídě, které zahrnuje podle etap tři druhy činností: projektování, realizaci projektu v interakci se žáky a hodnocení. Doplňkové činnosti se uskutečňují nad rámec vyučování, mají však i přesahy do vyučování a Vašutová (2004, s. 77-78) je kategorizuje do následujících druhů: konzultační, koncepční, administrativní, operativní, styk s veřejností a spolupráce se sociálními a výchovnými partnery, profesní seberozvoj učitelů a specifické činnosti. 
Rozsah a podíl profesních činností učitele jako průměr v hodinách týdne zkoumal Urbánek (2005), který obdobně jako Vašutová (2004) a Průcha (2002) vymezil za základní činnost vyučování, kterou doplňuje dalšími kategoriemi činností:

- Přímá výuka a s ní spojené aktivity: tj. vlastní výuka; doučování; příprava na výuku; př́íprava pomůcek; opravování, hodnocení; klasifikace a jiné formy hodnocení.

- Činnosti učitele s výukou související: tj. dozory; suplování, pohotovost; kontakt s rodičí; tř́dnické práce; správa kabinetů, učeben, knihovny; žákovské soutěže (olympiády apod.); administrativní práce.

- Porady a schůze; vzdělávací aktivity; mimoškolní aktivity; veřejná činnost; a jiné jsou dalšími skupinami definovanými uvedeným autorem (Urbánek, 2005, s. 127; Urbánek, 2009, s. 406).

Pro doplnění šíře výzkumů zaměřených na identifikaci učitelských činností je vhodné připomenout, že výzkumně byla řešena i problematika činností začínajících učitelů. Pařízek (1988) se věnoval komparaci činností začínajících a zkušených učitelů. Speciálně se profesním činnostem začínajících učitelů věnoval Šimoník (1994) a na obtíže zahraničních začínajících učitelů poukázal Průcha (2002, s. 212).

Švec (2005) poukazuje, že hlubšímu porozumění učitelské profesi může napomoci strukturování profesních kompetencí učitele, které směřuje i ke kvalitní sebereflexi učitele a vlastnímu zdokonalení profese. Za podstatnou profesní kompetenci učitelů označuje Kurelová (2008) profesní činnosti.

V současné době je v základních kurikulárních dokumentech, taktéž i v Rámcovém vzdělávacím programu pro předškolní vzdělávání (2004) uvedeno, že pro úspěšný výkon učitelské profese by měl být učitel vybaven pedagogickými kompetencemi. Vašutová prezentuje soubor kompetencí pro všechny kategorie učitelů: kompetenci předmětovou; didaktickou a psychodidaktickou; pedagogickou; diagnostickou a intervenční; sociální; psychosociální a komunikativní; manažerskou a normativní; profesně a osobnostně kultivující a ostatní předpoklady. Pro kategorii učitelek mateřských škol zachovává stejnou strukturaci, avšak charakteristiky těchto kompetencí specifikuje dle rolí a činností (Vašutová, 2004, s. 105). 
Počet doposud realizovaných a prezentovaných výzkumů v oblasti profesních činností učitelek mateřských škol je v České republice velmi omezený (Burkovičová, 2012). Za důležité proto autorky považují zmínit skutečnost, že v průběhu výzkumného šetření, prezentovaného ve třetí kapitole probíhal současně mezinárodní výzkum Profesia učitel' preprimárnej edukácie a učitel' primárnej edukácie v dynamickom poňatí, jehož cílem bylo, sestavit profesiogram učitele preprimárního a primárního vzdělávání. Zúčastnily se ho týmy ze Slovenska, Polska a České republiky. Pro zjištování dat k sestavení profesiogramu bylo pro učitele v preprimárním vzdělávání navrženo 5 hlavních kategorií činností (činnosti př́ímo související s edukačními aktivitami a jejich přípravou; ostatní činnosti související s edukací; činnosti vyplývající z jiných funkcí učitele; vzdělávaní a sebevzdělávání a mimoškolní a veřejné činnosti) a v rámci nich pak celkem 25 činností blíže tyto kategorie specifikující (Kasáčová et al., 2011, s. 228-229).

\section{Specifika profese učitelek mateřských škol v českém prostředí}

Pro následnou analýzu profesních činností reálně vykonávaných učitelkou mateřské školy považují autorky za důležité seznámit čtenáře se vybranými charakteristikami profese, at' již z hlediska stručného historického diskurzu, specifičnosti pregraduální přípravy učitelek, kvalifikačních požadavků na profesi atd.

Dle školského zákona (2004) předškolní vzdělávání v České republice představuje počáteční stupeň veřejného zdělávání a dle mezinárodní klasifikace zabezpečuje první etapu, která bývá označována jako preprimární vzdělávání (ISCED 0). V posledních době je zdůrazňován význam předškolního vzdělávání v kontextu celoživotního vzdělávání jedince, především v souvislosti s vytvořením dobrých předpokladů pro pokračování ve vzdělávání (OECD, 2012). Předškolní vzdělávání v České republice není povinné (i když o jeho zavedení je zmínka v programovém prohlášení současné vlády), ale těší se všeobecnému zájmu rodičovské veřejnosti, nebot' cca $90 \%$ dětí předškolního věku před zahájením povinné školní docházky navštěvuje mateřskou školu (Výroční zpráva..., 2013). Roli učitele lze vymezit na základě struktury profesních činností, přičemž oborem profesních činností učitelky mateřské školy je výchova a vzdělávání dětí předškolního věku v úzké vazbě na rodinnou výchovu. 


\subsection{Kvalifikační požadavky na profesi učitelky mateřských škol}

Prvním výrazným specifikem profese učitelek mateřských škol je odlišný zákonný požadavek v získání odborné kvalifikace. Učitel je dle současné české platné legislativy (Zákon č. 563/2004 Sb., o pedagogických pracovnících, 2012) pedagogický pracovník, který vykonává př́mou pedagogickou činnost. Kvalifikačním předpokladem obecně pro kategorii učitelů je v České republice požadováno na všech stupních a druzích škol vysokoškolské vzdělání. Učitel prvního stupně základní školy, učitel druhého stupně základní školy, učitel střední školy, učitel vyšší odborné školy i učitel uměleckých odborných předmětů v základní umělecké škole, střední odborné škole a konzervatoři a učitel jazykové školy s právem státní jazykové zkoušky získává odbornou kvalifikaci vysokoškolským vzděláním, avšak učitelce mateřské školy a učitelce přípravné tř́́dy základních škol postačuje středoškolské vzdělání s maturitní zkouškou získanou ukončením v oboru vzdělání zaměřeném na př́ípravu učitelů mateřské školy.

Zákon o pedagogických pracovnících (2012) sice uvádí další možnosti získání odborné kvalifikace, konkrétně vyšší odborné a vysokoškolské vzdělání, ale $\mathrm{k}$ uzákonění požadavku vysokoškolského vzdělání pro učitelky mateřských škol bohužel ani v této novele nedošlo. Je vhodné připomenout, že již před 14 lety byl expertním týmem OECD formulován požadavek v Národní zprávě o stavu prededškolní výchovy, vzdělávání a péče o děti předškolního věku $v$ České republice $(2000, \mathrm{~s}$. 57) přesunout vzdělávání předškolních pedagogů do terciální sféry.

Většina učitelek mateřských škol má středoškolské vzdělání a nepříznivým faktem je 17,7 \% nekvalifikovaných pedagogů (přepočtený počet nekvalifikovaných, Výroční zpráva..., 2013). Nejméně kvalifikovaných učitelů je ve Středočeském kraji a Praze.

\subsection{Historický vývoj profese učitelky mateřských škol}

Od prvopočátku se v profesní přípravě odrážela specifičnost práce učitelek mateřských škol, která zahrnovala dvě neoddělitelné složky: osobnostní a odborné předpoklady $\mathrm{k}$ výkonu učitelského povolání. Již v Ministerském výnosu z roku 1872 byly legislativně stanoveny zkoušky učitelské způsobilosti (Opravilová, 2007). Základní podmínkou získání učitelské způsobilosti bylo vedle osobnostních předpokladů prokázání dobré teoretické i praktické znalosti problematiky mateřských škol. 
V českém prostředí se první veřejné předškolní instituce objevují od počátku třicátých let v podobě opatroven, útulků, dětinců, dětských škol a dětských zahrádek. Významným mezníkem bylo založení pražské vzorné opatrovny na Hrádku v roce 1832, v jejímž čele však nestála žena, ale učitel Jan Vlastimír Svoboda. Do roku 1919 mohla ve veřejné předškolní instituci pracovat pouze neprovdaná žena. Zajímavým historickým vývojem prošlo i samotné označení profese od pěstounky (Opravilová, 2007), přes učitelku mateřské školy až k předškolnímu pedagogovi (RVP PV, 2004, s. 44).

Nejprve byla profesní příprava učitelek mateřských škol realizována formou jednoročních kurzů při ženských učitelských ústavech, po roce 1914 získávaly učitelky mateřských škol svou kvalifikaci především na dvouletých ústavech pro vzdělávání učitelek mateřských škol. $V$ roce 1934 výnosem ministerstva školství a národní osvěty bylo zavedeno užívání jednotných názvů: mateřská škola a místo pěstounka označení učitelka mateřské školy.

Za připomenutí jistě stojí, že myšlenky o vysokoškolském vzdělávání učitelek mateřských škol zazněly již v roce 1920 na I. sjezdu českého a slovenského učitelstva a byly zahrnuty do návrhu školského zákona, který bohužel nebyl schválen (Uhlířová, 2007). Vysokoškolské vzdělávání učitelek mateřských škol bylo krátce realizováno nejprve studiem dvouletých kurzů ve třicátých letech 20. století, následně opět krátkodobě v padesátých letech 20. století na pedagogických fakultách. Od roku 1950 se pregraduální př́íprava učitelek mateřských škol vrátila opětovně na středoškolskou úroveň a od roku 1970 vznikl duální systém pregraduální př́pravy učitelek mateřských škol, kdy bylo možno získat kvalifikaci středoškolským studiem (ISCED 3) či magisterským studiem na pedagogické fakultě v Praze a Olomouci (ISCED 5). Od roku 1995 přibyla zákonná možnost získat vzdělání na vyšších odborných školách.

\subsection{Demografické charakteristiky profese učitelky mateřských škol}

Socioprofesní skupina pedagogů mateřských škol je velmi specifická (Burkovičová, 2012; Syslová, Borkovcová, \& Průcha, 2014; Šmelová \& Nelešovská, 2009), nebot' se v současné době vyznačuje silnou feminizací (Průcha, 2009; Výroční zpráva..., 2013) a tzv. trojkolejností v pregraduálním vzdělávání. V mateřských školách je $\mathrm{z}$ hlediska gendrového vyvážení zastoupen pouze nepatrný počet mužů, který se v procentuálním vyjádření pohybuje kolem hodnoty $0,2 \%$. 
Z hlediska věkové struktury jsou nejvíce zastoupeny učitelé ve věku 36-55 let. Sice je patrné zvýšení podílu učitelů mladší generace (do 25 let ze $4,5 \%$ na $7,5 \%$ a ve věku $26-35$ let z $11,4 \%$ na $13,7 \%$ ), avšak současně přibývá kategorie starších učitelů nad 46 let (ÚIV, 2011).

V České republice připadá v mateřské škole na jednu učitelku (bez asistentů) 13,7 dítěte. V současné době však mnohé mateřské školy nedokáží uspokojit poptávku rodičů o umístění jejich dítěte z důvodu přeplněných kapacit škol, takže běžně ve tř́íách je 28 dětí předškolního věku.

\subsection{Profesní profil učitelky mateřských škol}

V současné době je obecně pro výkon učitelské profese požadován soubor osobnostních a odborných předpokladů, které jsou označovány jako profesní kompetence (Vašutová, 2001; Průcha, 2002; Helus, 2009; Syslová, 2013). Profesní profil učitelky mateřské školy se skládá z odborných kompetencí a osobnostních předpokladů, který rozpracovala Vašutová (2001) do návrhu profesního standardu dle kompetencí (předmětová, didaktická a psychodidaktická, pedagogická, diagnostická a intervenční, sociální, psychosociální a komunikativní, manažerská a normativní, profesně a osobnostně kultivující). Při konkrétní interpretaci profilu učitele je nutno zohlednit, že v mateřských školách pracují učitelé s dětmi zpravidla od tří do šesti až sedmi let (někdy i s dětmi mladšími tří let) a musí zohledňovat nejenom věková a vývojová specifika, ale především respektovat jejich potřeby a zájmy. Ve srovnání s učiteli primárního či sekundárního stupně realizují vzdělávání především metodami založenými na prožitkovém a kooperativním učení hrou, nebot' v předškolním období významnou roli v procesu učení sehrává spontánní učení (RVP PV, 2004).

Profesní činnosti učitelky mateřské školy v českém prostředí ovlivňuje více činitelů: česká učitelská a školská tradice; společensko-politický, kulturní, ekonomický vývoj české společnosti; současný určitý životní styl české společnosti; přijímání a oceňování profese učitele mateřské školy českou společností; současné i minulé modely vzdělávání dítěte předškolního věku v české mateřské škole. Významným činitelem je současný Rámcový vzdělávací program pro předškolní vzdělávání (dále RVP PV, 2004) a také individuální charakteristiky učitelů jako osobností, do nichž se promítá to, v jakém prostředí vyrůstali, jakou životní, studijní, profesní dráhou prošli a s jakými dopady na vlastní osobnost. Profese učitelky mateřské školy má nejvyšší počet hodin 
př́mé práce u dětí za týden ve srovnání s učiteli dalších stupňů škol (1. stupně ZŠ, 2. stupně ZŠ a středních škol).

Je zřejmé, že s ohledem na specifika předškolního vzdělávání, budou i profesní činnosti učitelky mateřské školy odlišné od profesních činností učitelů základních a středních škol. To, co učitelky mateřských škol ve své profesi vykonávají, je zpravidla vymezeno právními předpisy, ale mnohdy nevypovídá o reálně vykonávaných činnostech učitelů. Autorky považují za velmi důležité poukázat na faktický repertoár činností učitelek mateřských škol v souvislostech se zajištěním kvality předškolního vzdělávání.

\section{Seznámení s realizovaným výzkumem}

V následujícím textu vycházíme z publikovaného výzkumu (Burkovičová, 2012), který byl realizován třemi na sebe navazujícími dílčími výzkumnými šetřeními s dílčími výzkumnými cíli. Konkrétně analyzujeme základní profesní činnosti učitelů mateřských škol, které pomocí dalšího výzkumného šetření zkoumáme v průběhu jednoho školního roku.

Hlavním cílem výzkumu bylo identifikovat, pojmenovat a zaznamenat učitelkou české mateřské školy běžného typu² profesní činnosti jí reálně vykonávané v mateřské škole, popř i v jiném prostředí, ověřit jejich existenci a zjistit ve třech obdobích školního roku podíl časového vytížení učitelky realizací vybraného druhu činnosti v rámci určené týdenní přímé práce s dětmi.

\subsection{Identifikace profesních činnosti učitelek mateřských škol}

Prvním dílčím cílem výzkumného šetření bylo identifikovat, pojmenovat a zaznamenat do verbálního protokolu (Skořepa, 2005, s. 62) učitelkou české mateřské školy běžného typu profesní činnosti jí reálně vykonávané v mateřské škole, popřs i v jiném prostředí.

Výzkumné šetření bylo heuristické (vyhledávající) a popisné a zúčastnilo se ho 170 probandek, které pracují jako učitelky mateřských škol. Byl uplatněn kvalitativní přístup sběru dat bez stanovení základních proměnných. Bereme v úvahu, že profesní znalosti učitele toho zahrnují více, než může tento sub-

2 Jde o mateřskou školu, v níž je týmem učitelek vytvářen vzdělávací program vycházející z RVP PV na školní a třídní úrovni s respektováním místních zvyků a tradic ve vztahu k tamější společenské komunitě, př́padně pouze s alternativními prvky jiných vzdělávacích programů. Mateřská škola je zapsaná v síti škol. 
jekt ř́íci nebo napsat (Švec, 2005, s. 35), a využívá-li učitel svých implicitních znalostí, dokáže si poradit i v náročných pedagogických situacích, tedy dokáže činnost uskutečnit (Švec, 2005, s. 76). Avšak domníváme se, že je potřeba, aby učitelka byla schopná o tom, co koná, odpovídajícím způsobem ostatní informovat. V této etapě výzkumu jsme další data o probandkách nezjištovali a na probandky jsme neměli žádné požadavky.

V záznamových arších, vyplněných probandkami, byly jimi uvedeny činnosti, které byly sice různě pojmenovány, ale evidentně se jednalo o činnosti tytéž, byly formulovány v různé úrovni obecnosti, konkretizace a specifikace. Učitelky detekovaly, pojmenovaly a uvedly činnosti vykonávané jednak v pracovní době stanovené pro př́mou pedagogickou činnost v MŠ a vymezeném prostoru, ale také $\mathrm{v}$ době, která předcházela či následovala po př́mém kontaktu s dětmi a spadala do týdenní pracovní doby a i činnosti vykonávané po pracovní době, ale vztahující se k profesi.

Za účelem generování pojmenování činností jsme zvažovali: co, kde, kdy a jak ${ }^{3}$ byla činnost učitelkou realizována. Ze všech původních pojmenování probandkami jsme pak vybrali to pojmenování činnosti, které vykázalo nejvyšší četnost nebo bylo probandkami podle našeho úsudku vzhledem k náplni činnosti nejvhodněji formulováno. Jako konečné pojmenování činnosti byly tedy použity in vivo kódy, tedy výrazy, které použily probandky. Kupřr. probandkami uvedené alternativy pojmenování: hry dětí v průběhu ranního scházení dětí, hraní dětí, volné hry ráno, neorganizovaná ranní činnost dětí, ranní neřízené hry. Námi vybraná formulace = in vivo: ranní hry.

Následně jsme uskutečnili rozbor identifikovaných činností, vyvodili základní charakteristiky pro jejich třídění, sdružování a bližší specifikaci. Strukturu jsme uplatnili při vyvozování našeho pojmenování činností.

Jako aktéři se v analyzovaných činnostech objevovali: učitelka, rodiče, zákonný zástupce a občan. $V$ činnostech učitelky uskutečňovaly kontakty s dítětem, v nichž měly převahu verbální či nonverbální komunikace s dítětem nebo $v$ kontaktech s dítětem převažovalo řízení a organizace dětí. Četnost cílové skupiny představovala: tř́du dětí, skupinu dětí nebo jedno dítě. Činnosti probíhaly v prostoru budovy mateřské školy nebo mimo ni (např. na zahradě, na vycházce městem). Vyskytovaly se následující situace: některá z etap analýzy potřeb dětí; proměny situace; zdůvodňování situace některému z akté-

3 S využitím Švaříček \& Šed'ová, et al (2007, s. 6 a 212). 
rů; ohrožení dětí; edukace dětí. Strategií dosažení cíle bylo: vyhodnocení situace učitelkou; projednávání; řešení. Charakteristika čas byla sycená: uspořádáním dne dětí; dnem jako časovou jednotkou. Interní strategii: př́mou edukaci dítěte; rozvoj osobnosti dítěte; edukaci dětí i dospělých v mateřské škole; zajištění bezpečí dítěte; zajištění bezpečí dětí a dospělých v mateřské škole vnímáme jako záměr. Přímá činnost s dětmi; profesionální péče o děti; dohled nad dětmi; plánování a projektování; evaluační činnost; sebevzdělávání; administrativní činnost, spolupráce, jiná činnost - každá z těchto činností má jiný, určitý charakter.

\subsection{Prověřování identifikovaných profesních činností}

Rozhodli jsme se oveřit existenci identifikovaných profesních činností reálně vykonávaných učitelkou mateřské školy a př́padně identifikovat nezjištěné reálně vykonávané profesní činnosti.

Sběr dat proběhl výzkumnou metodou terénního pozorování učitelek dětí předškolního věku $\mathrm{v}$ průběhu dne. Učitelky byly pozorovány od doby, kdy začínaly pracovat (od 6.00 hod, od 6.30 hod, dvě probandky od 7.00 hod) do skončení provozní doby mateřské školy, což bylo do 16.30 hod. Probandky uvedly, že v období probíhajícího výzkumu veškeré činnosti (mimo př́mou práci s dětmi) dotýkající se jejich zaměstnání vykonávají pouze v budově mateřské školy a jejich přilehlých prostorách. Výzkumný soubor byl vytvořen na základě indikátoru délka pedagogické praxe v mateřské škole. Jednalo se o 5 podskupin probandek, a to $\mathrm{s}$ délkou pedagogické praxe od 2 do 5 let; od 6 do 10 let; od 11 do 15 let; od 16 do 20 let a nad 20 let. Pozorováno bylo 10 probandek-učitelek mateřských škol, po dvou učitelkách z každé podskupiny, které byly ochotny pozorování podstoupit, a to každá 14 dní.

Po realizaci pozorování jsme uskutečnili deskripci a analýzu průběhu pozorovaných pedagogických situací a v nich učitelkou uskutečněných činností, a to podle dř́ve vyvozených charakteristik. Identifikovali jsme další činnosti, které učitelky do archů v prvním výzkumném šetření nezaznamenaly. Činnosti identifikované ve dvou dílčích výzkumných šetřeních jsme rozdělili na dvě hlavní skupiny (blíže viz tabulka 2), a to skupiny: činností př́ípravných a realizačních. 
Tabulka 2

Základní kategorizace profesních činností učitelky mateřské školy

\begin{tabular}{|c|c|}
\hline Přípravné činnosti & Realizační činnosti \\
\hline $\begin{array}{l}\text { - Sebevzdělávací činnosti (využití } \\
\text { předmětových kompetencí) }\end{array}$ & $\begin{array}{l}\text { - Přímá pedagogická činnost podle připraveného } \\
\text { edukačního projektu či jeho části }\end{array}$ \\
\hline - Administrativní činnosti & - Profesionální péče o dítě \\
\hline • Plánování a projektování & •Dohlížení \\
\hline \multirow[t]{2}{*}{ - Participace na správě a samosprávě školy } & - Zajištování bezpečnosti a ochrany zdraví dětí \\
\hline & $\begin{array}{l}\text { • Vzájemná spolupráce, poradenská, metodická, } \\
\text { konzultační a organizační činnost }\end{array}$ \\
\hline
\end{tabular}

Ve skupině činností přípravných jsme identifikovali podskupinu sebevzdělávací činnosti, do níž jako druhy činností jsme zařadili: samostudium a sebevzdělávání účastí v institucionálním vzdělávání. Druhou podskupinou jsou administrativní činnosti s druhy činností: administrativní činnosti spojené s konkrétním dítětem nebo spojené s přímou pedagogickou činností učitelky mateřské školy. Třetí podskupinou je plánování a projektování $s$ druhy činností: plánování, projektování edukace dětí a příprava a organizace podmínek pro př́mou pedagogickou činnost s dětmi. Čtvrtou podskupinou jsou evaluační činnosti s druhy činností: analýza a vyhodnocování výtvarných, grafických a jiných produktů dětí; analýza a hodnocení výsledků dětí dosažených v kognitivní, emočně-sociální a psychomotorické oblasti v př́ímé pedagogické činnosti s dětmi a v profesionální péči o dítě; sebereflexe a sebehodnocení průběhu své přímé pedagogické činnosti s dětmi a profesionální péče o dítě. Poslední podskupinou je participace na správě a samosprávě školy s druhy činností: výzdoba a úprava třídy, školy a odborná péče o kabinety, knihovny a další zařízení sloužící potřebám vzdělávání dětí i ostatních zaměstnanců mateřské školy.

Ve skupině činností realizačních jsme identifikovali podskupinu přímá pedagogická činnost podle připraveného edukačního projektu či jeho části, kterou pak podle toho, zda je uskutečňovaná s třídou dětí, se skupinou dětí nebo je individuálně zaměřená; zda je zařazená podle uspořádání dne dětí v budově mateřské školy nebo se uskutečňuje při pobytu venku; zda v ní převažuje řízení a organizace či v ní převažuje verbální či nonverbální komunikace s dětmi, jsme rozdělili na jednotlivé druhy, $v$ nichž se objevují tyto uvedené charakteristiky činnosti. 
Př́ílad druhu činnosti: přímá pedagogická činnost podle připraveného edukačního projektu, či jeho části, s třídou dětí zařazená podle uspořádání dne dětí v budově mateřské školy s převahou řízení a organizace.

Další podskupina je profesionální péče o dítě včetně verbální i nonverbální komunikace s dítětem na základě analyzovaných potřeb dítěte, a to $\mathrm{v}$ budově mateřské školy nebo mimo ni. Jedná se tedy o dva samostatné druhy činností.

Samostatnou podskupinou představuje dohlížení, které zahrnuje další druhy činností podle toho, zda je dohlížení zaměřeno na třídu dětí, na skupinu dětí nebo je individuálně zaměřené; zda vychází z uspořádání dne dětí v budově mateřské školy, je uskutečňováno podle aktuální situace při pobytu venku nebo je odpovědí na analyzované potřeby dětí. Dohlížení na třídu dětí vycházející z uspořádání dne dětí v budově mateřské školy.

Zajištování bezpečnosti a ochrany zdraví dětí je další podskupinou činností, kdy podle její charakteristiky byly identifikovány druhy: zajištování bezpečnosti a ochrany zdraví dětí v budově mateřské školy a mimo budovu.

Vzájemná spolupráce, poradenská, metodická, konzultační a organizační činnost je poslední podskupinou činností, kterou jsme na druhy činností specifikovali podle následujících charakteristik: zda se uskutečňuje s učitelkou v kmenové tř́idě mateřské školy; s ostatními učitelkami i pedagogickými pracovníky i mimo ni; s nepedagogickými spolupracovníky mateřské školy i mimo mateřskou školu, s dalšími subjekty; se zákonnými zástupci dětí; při vedení pedagogické praxe; při přípravě mimořádných akcí nebo při metodologické činnosti a metodologická činnost. (Burkovičová, 2012, s. 133-136)

Jak je z uvedené kategorizace patrné, druhy činností se liší specifikací (... s učitelkou $\mathrm{v}$ kmenové tř́́dě mateřské školy či ... s ostatními učitelkami i pedagogickými pracovníky i mimo mateřskou školu), mají však společnou podstatu činnosti (vzájemná spolupráce, poradenská, metodická, konzultační a organizační činnost...). Podle ní jsme činnosti sdružovali do větších celků. Vzhledem k označení hlavní skupina pro činnosti př́ípravné a realizační jsme podle jejich podstaty tyto skupiny činností ve větších celcích označili jako podskupinu, kdy její pojmenování odráží právě společnou podstatu jednotlivých druhů činností. 


\subsection{Zjištování časového vytížení učitelky - porovnání v časových etapách}

Cílem posledního dílčího výzkumného šetření bylo zjistit ve třech obdobích školního roku podíl časového vytížení učitelky realizací vybraného druhu činnosti v rámci určené týdenní přímé práce s dětmi.

Ve školním roce 2013/2014 po dobu 14 kalendářních dní následujících po sobě, $\mathrm{v}$ němž $\mathrm{v}$ mateřské škole nejsou plánovány mimořádné akce nebo je učitelky nepřepokládají; ve třech ročních obdobích, a to říjen, listopad; leden, únor a květen učitelky do výzkumných archů zapisovaly u jednotlivých druhů činností vytíženost těmito činnostmi v době od 7.00 hod do 16.00 hod, a to po hodinách. $V$ době od 16.00 do 24.00 hod probandka zapsala svou vytíženost činností celkově. První etapa byla záměrně naplánována nejdříve od října, nebot' jsme vycházeli z předpokladu, že adaptace každého z nově zařazených dětí již proběhla a děti, jež do mateřské školy již dříve docházely, si po prázdninách opět přivykly známému průběhu dne i týdne a že již obnovily kontakty mezi sebou. Ve školním roce práce učitelky má již od ř́jna standardní průběh. Leden a únor představoval 2. etapu a květen 3. etapu výzkumného šetření. Na poslední etapu nebyly vyčleněny 2 kalendářní měsíce, poněvadž v červnu v MŠ bývají pro děti zařazovány mimořádné kulturní, sportovní a jiné akce.

Výzkumný soubor byl opět vytvořen na základě hlavního indikátoru délka pedagogické praxe $v$ mateřské škole uplatněného $\mathrm{v}$ přechozím dílčím výzkumném šetření. Byly získány zcela vyplněné záznamy ze všech tří období od 112 probandek. Četnost odevzdaných, zcela vyplněných archů se s délkou pedagogické praxe učitelek zvyšovala.

Vzhledem k tomu, že za jednu z nejvýznamnějších činností učitelky v mateřské škole považujeme druh činností z podskupiny př́má pedagogická činnost podle připraveného edukačního projektu či jeho části s bližší specifikací $s$ tř́dou dětí zařazená podle uspořádání dne dětí v budově MŠ s převahou ř́zení a organizace z hlavní skupiny činností realizačních, byl formulován následující předpoklad: Nejvyšší časová zátěž učitelek tímto druhem činnosti bude ve školním roce v květnu, a to v době mezi 9.00 a 10.00 hod. Tento předpoklad byl ověřován pomocí časového snímkování.

4 Výzkumný arch byl koncipován tak, jak byl sestaven výzkumný arch pro výzkum profesních činností ve výzkumném projektu APVV - 0026-07 Profesia „učitel preprimárnej edukácie“ $a$ „učitel primárnej edukácie“ $v$ dynamickom poňatí na Pedagogické fakultě UMB v Bánské Bystrici, jehož byla jedna z autorek textu účastna za českou stranu. 
Tabulka 3

Přímá pedagogická činnost podle připraveného edukačního projektu či jeho části s třídou dětí zařazená podle uspořádání dne dětí v budově MŠ s převahou ř́zení a organizace

\begin{tabular}{|c|c|c|c|c|c|c|c|c|c|c|c|c|c|}
\hline $\begin{array}{l}\text { Od - do } \\
\text { (hodiny) }\end{array}$ & $\begin{array}{l}7: 00- \\
8: 00\end{array}$ & $\begin{array}{l}8: 00- \\
9: 00\end{array}$ & $\begin{array}{l}9: 00- \\
10: 00\end{array}$ & $\begin{array}{l}10: 00- \\
11: 00\end{array}$ & $\begin{array}{l}11: 00- \\
12: 00\end{array}$ & $\begin{array}{l}12: 00- \\
13: 00\end{array}$ & $\begin{array}{l}13: 00- \\
14: 00\end{array}$ & $\begin{array}{l}14: 00- \\
15: 00\end{array}$ & $\begin{array}{l}15: 00- \\
16: 00\end{array}$ & $\begin{array}{l}16: 00 \\
\text { a později }\end{array}$ & $\begin{array}{l}\text { Denně } \\
\text { minut }\end{array}$ & $\begin{array}{l}\text { Týdně } \\
\text { minut }\end{array}$ & $\%$ \\
\hline \multirow{2}{*}{$\begin{array}{l}\text { 1. etapa } \\
\text { Říjen, } \\
\text { listopad }\end{array}$} & 4,59 & 8,12 & 11,41 & 5,58 & 2,36 & 0,45 & & & & & $32^{\prime} 31^{\prime \prime}$ & $162^{\prime} 33^{\prime \prime}$ & 9,1 \\
\hline & & & & 5,58 & 2,36 & 0,45 & 0,24 & 2,59 & 3,29 & 0,35 & $14^{\prime} 52^{\prime \prime}$ & $74^{\prime} 18^{\prime \prime}$ & 4,1 \\
\hline 2. etapa & 0,24 & 3,01 & 4,54 & 25,21 & 12,49 & 0,35 & & & & & $45^{\prime} 50^{\prime \prime}$ & $230^{\prime}$ & 12,7 \\
\hline $\begin{array}{l}\text { Leden, } \\
\text { únor }\end{array}$ & & & & 25,21 & 12,49 & 0,35 & 0,16 & 0,3 & 6,13 & 0,11 & $44^{\prime} 45^{\prime \prime}$ & $223^{\prime} 45^{\prime \prime}$ & 12,5 \\
\hline 3. etapa & 0,15 & 1,26 & 5,28 & 28,59 & 10,23 & 0,34 & & & & & $45^{\prime} 51^{\prime \prime}$ & $229^{\prime} 15^{\prime \prime}$ & 12,7 \\
\hline Květen & & & & 28,59 & 10,23 & 0,34 & 0 & 0 & 0 & 0 & $39^{\prime} 10^{\prime \prime}$ & $195^{\prime} 48^{\prime \prime}$ & 10,8 \\
\hline
\end{tabular}

Učitelky mají určenou dobu přímé práce s dětmi 31 hodin týdně, zpravidla 30 hod na tzv. ranní směně (RS) a 32 hod na tzv. odpolední směně (OS). $\mathrm{V}$ 1. etapě vykazuje vytížení námi sledovaným druhem činnosti učitelka na RS, tj. od 7.00 do 13.00 hod, průměrně denně 32' 31" (32 min 31 sekund), což činí průměrně týdně $162^{\prime} 33^{\prime \prime}$ a jedná se o 9,1\% z celkové vytíženosti učitelky námi sledovaným druhem činnosti. Učitelka na OS nastupující $\mathrm{k}$ dětem v 10.00 hod a ukončující svou přímou práci s dětmi po 16.00 hod je průměrně denně námi sledovaným druhem činnosti vytížená 14'52', což za celý týden činí průměrně 74'18"' a jde o 4,1\% vytíženosti sledovaným druhem činnosti z celkové týdenní doby přímé práce s dětmi.

Ve 2. etapě, tj. v období ledna a února, jsme zjistili nejdelší čas sledované činnosti mezi 10.00 a 11.00 hod. Nebývá příznivé počasí pro pobyt dětí venku. Současný model předškolního vzdělávání nevyžaduje striktní dodržování uspořádání dne, a tak učitelky řízené aktivity, volné hry a činnosti s dětmi rozprostřou do času po dopolední přesnídávce do doby oběda a námi sledovaný druh profesní činnosti učitelka vykazuje i v čase od 11.00 do 12.00 hod. Pro čas mezi 12.00 až 14.00 hod. bychom zdůvodnění opakovali tak, jak je uvedeno výše. Zvyšuje se zatížení učitelky činností mezi 15.00 až 16.00 hod v zimním období je možné, že učitelky posouvají odpolední činnosti dětí, v nichž dochází k uplatnění sledovaného druhu profesní činnosti učitelky. 
V této etapě je učitelka na RS námi sledovaným druhem činnosti denně vytížená $45^{\prime} 50^{\prime \prime}$, toto činí $230^{\prime}$ týdně a jedná se o 12,7 \% vytíženosti sledovaným druhem činnosti za týden z celkové týdenní doby přímé práce s dětmi. Učitelka na OS realizuje námi sledovaný druh činnosti průměrně $44^{\prime} 45^{\prime \prime}$ z celkové denní doby přímé práce s dětmi, jde průměrně o $223^{\prime} 45^{\prime \prime}$ týdně, tedy $12,5 \%$ $\mathrm{z}$ celkové týdenní doby př́mé práce $\mathrm{s}$ dětmi.

Ve 3. etapě nacházíme nejvyšší zatížení učitelky druhem profesní činností včase od 10.00 do 11.00 hod. Vkvětnu bývají obecně nejpř́íhodnější podmínky pro řízené činnosti $s$ dětmi. Děti již zpravidla zcela přivykly uspořádání dne, prostředí, mají navázány vztah s učitelkou, kontakty s kamarády. Proto realizace sledovaného druhu profesní činnosti učitelkou je $v$ uvedeném čase nejvyšší. Popsaným podmínkám na straně dětí a tomu, že v květnu již bývá prríznivé počasí, odpovídá i hodnota v čase mezi 11.00 a 12.00 hod. Učitelky druh sledované činnosti uplatňují při aktivitách realizovaných s dětmi venku. Ve 3. etapě učitelka na RS realizuje $45^{\prime} 51^{\prime \prime}$ sledovaným druhem činnosti, toto činí $229^{\prime} 15^{\prime \prime}$ z celkové týdenní doby přímé práce s dětmi, což činí 12,7\%. V průběhu OS učitelka činnost realizuje 39'10", za týden jde o 195'48", tedy $10,8 \%$ z celkové týdenní doby přímé práce s dětmi.

Lze tedy konstatovat, že výše zmíněný předpoklad nebyl potvrzen.

\section{Závěr}

Profese učitelky mateřské školy prošla zajímavým historickým vývojem od pěstounky k předškolnímu pedagogovi, na kterého jsou v současné době kladeny čím dál větší nároky s ohledem na zvyšující se význam předškolního vzdělávání. Práce učitelky mateřské školy má svá specifika. K hlavním činnostem profese učitelky mateřské školy patří plánování, organizace a evaluace vzdělávacího procesu, avšak profesní povinnosti předškolních pedagogů většinou přesahují hranice školy, nebot' učitel „dohlíží" na děti při školních akcích (školní výlet, školy v přírodě, kurzy plavání, lyžování atd.) podílí se na tvorbě prostředí, komunikuje s rodiči, spolupracuje s odborníky atd.

V omezeném čase, na omezeném výběrovém souboru jsme částečně osvětlili výkon profese současné učitelky mateřské školy v českém prostředí. Přínos práce vidíme $\mathrm{v}$ oblasti řešení jádra profese učitelky $\mathrm{v}$ běžné české mateřské škole. Uvědomujeme si, že úplné zachycení, kategorizace činností učitele mateřské školy, jejich odpovídající pojmenování vyjadřující jejich charakteristi- 
ku, a je stěží možné Zjištění podílu časového zatížení učitelky vybranou identifikovanou profesní činností v průběhu školního roku je prvním vstupem do hlubšího poznání profese podskupiny učitelů - učitelek mateřských škol. Profese má svá specifika. Proto zjistit, jak dlouho a kdy v průběhu denního a týdenního pracovního času realizují identifikované profesní činnosti, podá mj. obraz o jejich pracovním vytížení.

Zveřejněná data, informace, je potřeba hodnotit v kontextu období, v němž vznikla. S postupujícím vývojem české společnosti, v důsledku politických, ekonomických a jiných globálních změn, se mohou činnosti a jejich realizace $\mathrm{v}$ mateřských školách $\mathrm{v}$ budoucích letech a desetiletích různě proměňovat. Závěrem lze konstatovat, že profesním činnostem učitelek mateřských škol by bylo potřeba věnovat více pozornosti, nebot' $v$ českém prostředí výzkumy byly zaměřeny především na učitele základních a středních škol, o čemž svědčí i přehledová studie o výzkumech v oblasti předškolního vzdělávání (Syslová \& Najvarová, 2012). Získané závěry je možné využít nejenom ke zkoumání některých ukazatelů kvality profese učitelky mateřské školy, ale také při formování a ovlivňování budoucích či stávajících učitelek mateřských škol v rámci jejich pregraduální př́ípravy či kurzů dalšího vzdělávání.

\section{Literatura}

Blížkovský, B. (1997). Systémová pedagogika. Ostrava: Amosium.

Blížkovský, B., Kučerová, S., \& Kurelová, M. (2000). Středoevropský učitel na prahu učící se společnosti 21. století. Brno: Konvoj.

Burkovičová, R. (2012). Profesní činnosti učitelů mateřských škol a jejich výzkum. Ostrava: OU.

Dytrtová, R., \& Kruhutová, M. (2009). Učitel. Př́íprava na profesi. Praha: Grada.

Franiok, P., \& Knotová, D. (Eds.). (2008). Učitel a žák v současné škole. Brno: MU.

Helus, Z. (2009). Dítě v osobnostním pojetí. Praha: Portál.

Helus, Z. (2011). Jak chápat učitelství - impulzy pro pedagogické fakulty. Pedagogika, 61(4), 373-382.

Janík, T. (2005). Znalost jako klíčová kategorie učitelského vzdělávání. Brno: Paido.

Kasáčová, B., Babiaková, S., Cabanová, M., Filipiak, E., \& Seberová, A. (2011). Učitel'preprimárneho a primárneho vzdelávania. Profesiografia $v$ slovensko-česko-pol’skom výskume. Banská Bystrica: UMB.

Kot’a, J. (2008). Učitelská profese a změny perspektiv ve školské politice. In J. Novotná (Ed.), Škola v dialogu kultury, pedagogiky a společnosti (s.13-26). Liberec: TU Liberec.

Kurelová, M. (1998). Učitelská profese v teorii a v praxi. Ostrava: OU.

Kurelová, M. (2008). Proces reedukace a resocializace očima dětí a analýzy profesních činností vychovatelů a učitelů ve výchovných ústavech. In M. Kurelová, O. Sekera, \& H. Kubíčková (Eds.), Komunitní systém v resocializačních zařízeních pro adolescenty II. Ostrava: Pedagogická fakulta OU. 
Lazarová, B. (Eds.). (2001). Vzdělávat učitele. Brno: Paido.

Lukášová, H. (2003). Učitelská profese v primárním vzdělávání a pedagogická př́prava učitelů (teorie, výzkum, praxe). Ostrava: Pedagogická fakulta OU.

Mareš, J. (Ed.). (1993). Učitel - jeho př́prava a požadavky školské praxe: Sborník referátů z 2. konference České asociace pedagogického výzkumu. Ústí nad Labem: Pedagogická fakulta.

Národní zpráva o stavu predškolní výchovy, vzdělání a péče o děti předškolního věku v České republice. (2000). Praha: MŠMT.

OECD. (2012). Quality matters in early childhood education and care. Dostupné z http://www. oecd-ilibrary.org/education/quality-matters-in-early-childhood-education-and-careczech-republic-2012_9789264176515-en;jsessionid=2rfp29qdk04d1.x-oecd-live-02

Opravilová, E. (2007). Idea a realita vysokoškolského vzdělávání učitelek mateřských škol na pedagogické fakultě. In J. Kropáčková (Ed.), Idea a realita vysokoškolského vzdělání učitelek mateřských škol na pedagogické fakultě (s. 12-22). Praha: Pedagogická fakulta UK.

Opravilová, E. (1988). Dítě si hraje a poznává svět. Praha: SPN.

Pařízek, V. (1988). Učitel a jeho povolání. Praha: SPN.

Průcha, J. (2002). Učitel. Praha: Portál.

Průcha, J. (Ed.). (2009). Pedagogická encyklopedie. Praha: Portál.

Rámcový vzdělávací program pro předškolní vzdělávání. (2004). Praha: VÚP.

Rybičková, M., \& Hladík, J. (Eds.). (2009). Škola v proměnách: Učitel-žák-učivo. [CD-ROM] Zlín: Univerzita Tomáše Bati ve Zlíně.

Shulman, L. S. (1987). Knowledge and teaching: Foundations of the new reform. Harvard Educational Review, 57(1), 1-22.

Skořepa, M. (2005). Rozhodování jednotlivce. Teorie a skutečnost. Praha: Karolinum.

Spilková, V., \& Hejlová, H., et al. (2010). Příprava učitelů pro primární a preprimární vzdělávání $v$ Česku a na Slovensku. Praha: Pedagogická fakulta UK.

Spilková, V., \& Tomková, A., et al. (2010). Kvalita učitele a profesní standard. Praha: PedF UK.

Starý, K., Dvořák, D., Greger, D., \& Duschinská, K. (2012). Profesní rozvoj učitelů. Praha: Karolinum.

Syslová, Z., \& Najvarová, V. (2012). Předškolní vzdělávání v České republice pohledem pedagogického výzkumu. Pedagogická orientace, 22(4), 490-515.

Syslová, Z. (2013). Profesní kompetence učitele mateřské školy. Praha: Grada.

Syslová, Z., Borkovcová, I., \& Průcha, J. (2014). Vzdělávání a péče v raném věku. Komparace české a zahraniční situace. Praha: Wolters Kluwer.

Šimoník, O. (1994). Začínající učitel. Brno: MU.

Škoda, J., \& Doulík, P. (Eds.). (2004). Profese učitele a současná společnost. XII. Konference České asociace pedagogického výzkumu. Ústí nad Labem: Univerzita Jana Evangelisty Purkyně v Ústí nad Labem.

Šmelová, E., \& Nelešovská, A. (2009). Učitel mateřské školy v reflexi současných proměn. Olomouc: Univerzita Palackého.

Švaříček, R., Šed’ová, K., et al. (2007). Kvalitativní výzkum v pedagogických vědách. Praha:Portál. Švec, V. (1999). Pedagogická príprava budoucích učitelů: problémy a inspirace. Brno: Paido.

Švec, V. (Ed.). (2001) Profesní růst učitele. Sborník př́spěvkủ z 10. konference ČPdS. Brno: Konvoj. Švec, V. (2005). Pedagogické znalosti učitele: teorie a praxe. Praha: ASPI. 
Uhliŕrová, J. (2007). Význam historických aspektů ve vzdělání učitelek mateřských škol. In J. Kropáčková (Eds.), Idea a realita vysokoškolského vzdělání učitelek mateřských škol na pedagogické fakultě (s. 23-27). Praha: Pedagogická fakulta UK.

ÚIV. (2011) Školství pod lupou 2010.

Urbánek, P. (2001). Podpora práce učitelů ve světle současných problémů učitelství. In Učitelé jako profesní skupina, jejich vzdělávání a podpůrný systém. Sborník z celostátní konference. 2. díl. Praha: Pedagogická fakulta UK.

Urbánek, P. (2005). Vybrané problémy učitelské profese (aktuální analýza). Liberec: Pedagogická fakulta TU.

Urbánek, P. (2009). Pracovní zátěž a podmínky práce učitelů. In J. Průcha (Ed.), Pedagogická encyklopedie (s. 402-407). Praha: Portál.

Urbánek, P. (2011). Změny v sociálním klimatu učitelských sborů. In: Kam směřuje současný pedagogický výzkum? Sborník příspěvků 18. konference ČAPV. Liberec: TU v Liberci [CD-ROM].

Vašutová, J. (2001). Model tvorby profesního standardu učitelů. In E. Walterová (Ed.), Učitelé jako profesní skupina, jejich vzdělávání a podpưrný systém. Sborník z celostátní konference, 1. díl (s. 23-27). Praha: Pedagogická fakulta UK.

Vašutová, J. (2004). Profese učitele v českém vzdělávacím kontextu. Brno: Paido.

Vyskočilová, E. (2000). Místo učitelovy kondice v rámci pedagogických dovednosti. In V. Švec (Ed.), Monitorování a rozvoj pedagogických dovedností (s. 24-31). Brno: Paido.

Výroční zpráva české školní inspekce za školní rok 2012/2013. (2013). Praha: ČSI.

Walterová, E. (Ed.). (2001). Učitelé jako profesní skupina, jejich vzdělávání a podpưrný systém. Sborník z celostátní konference, 1. a 2. díl. Praha: Pedagogická fakulta UK.

Zákon č. 563/2004 Sb., o pedagogických pracovnících a o změně některých zákonů. Dostupné z http://www.msmt.cz/dokumenty/aktualni-zneni-zakona-o-pedagogickych-pracovnicich$\mathrm{k}$-1-zari

\section{Poděkování}

Autorky děkují redakci i oběma anonymním recenzentům za cenné rady a doporučení.

\section{Autorky}

Doc. PaedDr. Radmila Burkovičová, Ph.D., Ostravská univerzita, Pedagogická fakulta, Katedra preprimární a primární pedagogiky, Mlýnská 5, 70103 Ostrava, e-mail: radmila. burkovicova@osu.cz

PhDr. Jana Kropáčková, Ph.D., Univerzita Karlova, Pedagogická fakulta, Katedra primární pedagogiky, M. Rettigové 4, 11639 Praha, e-mail: jana.kropackova@pedf.cuni.cz 


\title{
Professional activities of kindergarten teachers in the light of current Czech research
}

\begin{abstract}
The paper presents the findings of research into the professional activities of kindergarten teachers in the Czech Republic and defines characteristics of the profession of kindergarten teachers in the Czech context. In the first part of the paper, the authors illustrate the current research interest in the teaching profession in the Czech Republic and summarise recent research on teachers' professional activities. In the second part of the paper, kindergarten teachers are introduced as a specific category of teachers in the Czech system of schooling. In the third part, a research survey is presented that aimed to identify, label and record professional activities of a kindergarten teacher in a dynamic perspective (throughout a school year). Towards the end of the paper, possible ways to make use of the research findings are implied.
\end{abstract}

Keywords: kindergarten teacher, professional activities, teaching profession, preprimary education

Šima K., \& Pabian, P. (2013). Ztracený Humboldtův ráj. Ideologie jednoty výzkumu a výuky ve vysokém školství. Praha: SLON.

Je jednota výzkumu a výuky samozřejmým a nezbytným základem moderního vysokého školství? Tato kniha ukazuje, že nikoliv, nebot' jednota nebyla nikdy ve skutečnosti realizována - podle autorů se jedná o ideologický princip, který realitu spíše zastírá a který je potřeba podrobit kritice. Interdisciplinární př́stup knihy sleduje vývoj této ideologie od 19. století do současnosti, v mezinárodním kontextu i v českých zemích, kde dominovala až do druhé světové války. Kniha vyvrací stereotyp odsuzující údajné oddělení výzkumu a výuky v socialistickém Československu a namísto toho poukazuje na inovativní transformaci humboldtovské ideologie do ideologické jednoty „vědy, vzdělání, výchovy a praxe“. Období po roce 1989 tudíž nepřineslo „obnovu jednoty výzkumu a výuky“; naopak vznikl systém, který propojování ideologicky vyžaduje, ale nepodporuje: školy se snažily vyhovět všeobecně deklarovanému nárůstu studijních míst a současně narůstajícím nárokům na vykazování výzkumných výsledků. Proto kniha navrhuje opustit ideologickou představu o jednotě „výzkumu“ a „výuky“ a navrhuje radikální změnu pohledu na hodnocení vzdělávání, hodnocení výzkumu i politiku diverzifikace. 